\title{
Edible and medicinal termites: a global overview
}

\author{
Rozzanna Esther Cavalcanti Reis de Figueirêdo ${ }^{1}$, Alexandre Vasconcellos ${ }^{1}$, lamara Silva Policarpo ${ }^{1 *}$ \\ and Rômulo Romeu Nóbrega Alves ${ }^{1,2}$
}

\begin{abstract}
Termites are mainly known for damage caused to human beings, both in urban and rural areas. However, these insects play an important role in the decomposition of organic matter in tropical regions and are important natural resources, which are widely used in traditional medicine and are also consumed by human populations in several parts of the world. This study aimed to catalogue termite species used worldwide through a literature review, characterizing them by its human populations' use. The results showed that at least 45 species of termites, belonging to four families, are used in the world, with 43 species used in human diet and/or in livestock feeding. Nine termite species are used as a therapeutic resource. There is an overlapping use of seven species. The use of termites was registered in 29 countries over three continents. Africa is the continent with the highest number of records, followed by America and Asia. The results suggest that, in addition to their ecological importance, termites are a source of medicinal and food resources to various human populations in various locations of the world, showing their potential for being used as an alternative protein source in human or livestock diets, as well as a source for new medicines.
\end{abstract}

Keywords: Ethnoentomology, Ethnozoology, Entomophagy, Entomotherapy

\section{Introduction}

Since ancient times, complex interactions among humans and other animals have been recorded, including harmonic and conflicting relations [1,2]. Termites illustrate this situation, as they can cause significant economic damage in urban and rural areas. At the same time, people from different parts of the world use them as food (for humans and livestock), and as a source material for popular medicine.

The importance of insects as a food source for humans is not surprising, since this is the group with the highest number of species in nature, thereby representing a significant biomass [3]. Considered as important natural resources, insects are, in many ways, a basic component of the diets of humans and other animals [4] and have played an important role as a source of medicinal resources [5-8]. Entomophagy, as the practice of using insects as a part of the human diet is called [9], has played an important role in the history of human nutrition in Africa, Asia and Latin America [10]. Another

\footnotetext{
*Correspondence: iamarasp@gmail.com

'Departamento de Sistemática e Ecologia, CCEN, Universidade Federal da Paraíba, Laboratório de Termitologia, 58051-900 João Pessoa, PB, Brazil Full list of author information is available at the end of the article
}

important use of insects by humans is medicinal use, featuring a practice known as entomotherapy $[8,11]$.

The negative view that most people have of termites prevails in many places, and it often masks the ecological role of these insects as mediators of the process of decomposition of plant organic matter and as agents with influence on the formation of soils and energy and nutrient flows, especially in tropical forests $[12,13]$. It should be emphasized that, from a utilitarian perspective, termites are commonly used insects in traditional popular medicine [6,14-16]. They are used in the treatment of various diseases that affect humans, such as influenza, asthma, bronchitis, whooping cough, sinusitis, tonsillitis and hoarseness $[17,18]$. Additionally, these animals have historically been an important source of food that may contribute to improving human diet, particularly for people who suffer from malnutrition due to a deficit of protein, as they are considered a nonconventional food with great economic and social importance. They have been consumed for generations in many regions of the world, a practice that has increased in popularity in recent years [19-24].

Despite their nutritional and medicinal importance to humans and livestock, termites are most recognized for 
their role as a plague, with a small widespread utility role. Therefore, the present review aims to catalogue the species of termites used worldwide, compiling the uses of these insects by human populations and delimiting their geographical spread. The research was mainly focused on the following questions: How many species of termites are used by human populations in the world? What are the uses of termite species? Which countries have the use of termite species?

\section{Methods}

To obtain data, available references that recorded the use of termites in the human and livestock diet were analysed, as well as the use of the species in traditional medicine. Information was collected from the analysis of published articles, books and book chapters available in online international databases such as ScienceDirect, CAPES Journals, SpringerLink, Google Scholar, Scopus and Web of Science and on scientific journal websites. The research in databases included the following keywords: termite + food + entomophagy - edible insects + termite - entomotherapy + termite - traditional medicine + termite.

Only identified species were compiled, excluding animals mentioned by their vernacular names or with only genus identification. The following references were consulted [4,6,11,14-16,18,20,23,25-103]. A database was created containing information about termite species, family names and the countries where their use was recorded. Taxonomic information about species has been updated, according to the Treatise on the Isoptera of the World [104].

\section{Results}

A total of 45 termite species belonging to four families were recorded as being used by human populations, with 43 species used in the human diet or for livestock feeding (Table 1) and nine species used as a therapeutic resource (Table 2). It can be seen that seven species can be used for both recorded purposes. Families reported in the studies were Hodotermitidae (2 spp.; 4\%), Kalotermitidae (2 spp.; 4\%), Rhinotermitidae (7 spp.; 6\%) and Termitidae (39 spp.; $87 \%)$. The species most frequently recorded in the studies were Macrotermes bellicosus (Smeathman, 1781) [ $\mathrm{n}=22$ studies], Macrotermes subhyalinus (Rambur, 1842) [ $\mathrm{n}=20$ studies], Nasutitermes macrocephalus (Silvestri, 1903) [ $\mathrm{n}=10$ studies] and Pseudacanthotermes spiniger (Sjoestedt, 1900) [ $\mathrm{n}=10$ studies]. It should be noted that termite species richness used by humans must exceed the number registered here, especially given that, in many studies, termites are mentioned only by their common name, or their identification is suitable only to genera.

Among the species used in human and/or livestock diet, the species Macrotermes bellicosus stood out, with a record of usage in several countries, especially in Africa. In addition, four species are used both in the human diet and for livestock feeding. Furthermore, five species had only one registered use, including Macrotermes herus (Sjoestedt, 1914), Macrotermes lilljeborgi (Sjoestedt, 1896) and Macrotermes muelleri (Sjoestedt, 1898), which are used only for livestock feeding.

For medicinal purposes, the use of ten species of termites was recorded. These species are used as an alternative treatment for physiological and spiritual problems. The species Nasutitermes macrocephalus was the most frequently recorded, and it is widely used in Brazil as a therapeutic resource for the treatment of asthma, hoarseness and sinusitis, among other diseases. Another example is Macrotermes nigeriensis, which is used in Nigeria in the treatment of wounds, sickness of pregnant women and as a charm for spiritual protection.

The use of termites was registered in 29 countries over three continents. Africa is the continent with the highest number of records (19 countries), followed by America (5 countries) and Asia (5 countries). Congo recorded the highest number of species used as food by humans and other animals (7 species recorded in the compiled studies), followed by China (6 spp.), Venezuela (6 spp.) and Zambia (5 spp.). Among species with a therapeutic use, there was a predominance of records in Brazil, suggesting that the use of termites in Brazilian popular medicine is relatively common. This kind of use was also recorded in other countries such as India (2 spp.), Zambia (1 sp.) and Nigeria (1 sp.).

\section{Discussion}

The information compiled in the present review shows that the interaction between the people and termites, throughout the world, has not been limited to conflicting relations, especially those related to their role as pests. The significant number of termite species used by people reflects the importance of these animals in different parts of the world, either for food or as a therapeutic resource, which are the main uses of these animals by human populations. Medicinal uses of termites in traditional systems of medicine are indicative that they may have potential as medicinal resources that deserve to be investigated from a pharmacological perspective. Similarly, their use as a protein source reveals that these insects may play important roles in human and other animals' diets, reinforcing a tendency indicated in previous studies $[8,14,16,57,76,77,91,105]$.

The high number of termites used as food corroborates previous studies that indicated that these animals have been widely consumed by people from all over the world because they provide relevant quantities of nutrients $[23,49]$. These animals are among the most commonly consumed insects on the planet, second only to 
Table 1 Termite species used as food or feed

\begin{tabular}{l} 
Species \\
\hline Hodotermitidae \\
Hodotermes mossambicus (Hagen, 1853) \\
Microhodotermes viator (Latreille, 1804)
\end{tabular}

\section{Kalotermitidae}

Kalotermes flavicollis (Fabricius, 1793)

\section{Rhinotermitidae}

Coptotermes formosanus (Shiraki, 1909)

Reticulitermes flavipes (Kollar, 1837)

Reticulitermes tibialis (Banks in Banks \& Snyder, 1920)

\section{Termitidae}

Cubitermes atrox (Smeathman, 1781)

Labiotermes labralis (Holmgren, 1906)

Macrotermes acrocephalus (Ping, 1985)

Macrotermes annandalei (Silvestri, 1914)

Macrotermes barneyi (Light, 1924)

Macrotermes bellicosus (Smeathman, 1781)

Macrotermes falciger (Gerstacker, 1891)

Macrotermes gabonensis (Sjoestedt, 1900)

Macrotermes gilvus (Hagen, 1858)

Macrotermes herus (Sjoestedt, 1914)

Macrotermes lilljeborgi (Sjoestedt, 1896)

Macrotermes michaelseni (Sjoestedt, 1914)

Macrotermes muelleri (Sjoestedt, 1898)

Macrotermes natalensis (Haviland, 1898)

Macrotermes nobilis (Sjoestedt, 1900)

Macrotermes renouxi (Rouland, 1993)

Macrotermes subhyalinus (Rambur, 1842)

Macrotermes vitrialatus (Sjoestedt, 1899)

Microcerotermes dubius (Haviland, 1898)

Microcerotermes serrula (Holmgren, 1912a)

Nasutitermes corniger (Motschulsky, 1855)

Nasutitermes ephratae (Holmgren, 1910b)

Nasutitermes macrocephalus (Silvestri, 1903)

Nasutitermes surinamensis (Holmgren, 1910b)

Odontotermes badius (Haviland, 1898)

Odontotermes capensis (De Geer, 1778)

Odontotermes feae (Wasmann, 1896)

Odontotermes formosanus (Shiraki, 1909)

Odontotermes kibarensis (Fuller, 1923)

\section{Use \\ $\overline{\text { Feed Food }}$}

Country(ies)

Reference(s)

X South Africa

[54]

[38]

X $\quad$ Brazil, Thailand

$[25,38,51,59]$

$X \quad$ China

$[25,38,57,98]$

X Thailand

$[20,25,38]$

X Mexico

[38]

X Indonesia [25,38]

$X \quad$ Colombia [25,53]

$X \quad$ China $\quad[25,38,57]$

X China [25,57,58,98]

X China $\quad[25,38,57,58,98]$

X $\quad X \quad$ Central African Republic, Congo, Democratic

Republic of the Congo, Nigeria, Angola,

Zambia, Kenya, Guinea, Senegal, Tanzania, Uganda

X Zimbabwe, Congo, Benin, Zambia, South Africa

$[20,25,38-40,48,49,54,77,103]$

X Congo

$[25,38]$

X Thailand, Malaysa $\quad[25,55,56]$

X Tanzania [35,79]

X Cameroon, Guinea [83,84,88]

X Malawi [103]

$X \quad$ Congo, Cameroon, Guinea $\quad[36,37,83]$

X Central African Republic, Zimbabwe,

$[20,25,27,32,38,41,49,95]$

Congo, Nigeria

Congo, Gabon, Cameroon

$[36,37,83]$

$[88,113]$

$[23,25,28-31,34,38,39,43,56,58,76$,

78,79,88,92-94,103]

$[25,30,31,38]$

$[25,56]$

$[25,56]$

$[25,53]$

$[25,53]$

$[25,53]$

$[25,53]$

$[25,30,38,47,51]$

$[25,38]$

$[25,38,57]$

$[25,58,59,100,103]$

[103] 
Table 1 Termite species used as food or feed (Continued)

\begin{tabular}{|c|c|c|c|c|}
\hline Odontotermes yunnanensis (Tsai \& Chen, 1963) & & $x$ & China & {$[25,58,59,100]$} \\
\hline Pseudacanthotermes militaris (Hagen, 1858) & $x$ & $x$ & Angola, Kenya, Tanzania, Uganda & {$[25,30,44,77,88,90,103]$} \\
\hline Pseudacanthotermes spiniger (Sjoestedt, 1900) & $x$ & $x$ & $\begin{array}{l}\text { Congo, Zambia, Tanzania, Kenya, } \\
\text { Uganda }\end{array}$ & {$[25,30,38,44,47,77,87,90,96,103]$} \\
\hline Syntermes aculeosus (Emerson, 1945) & & $x$ & Venezuela, Brazil & {$[25,54,93]$} \\
\hline Syntermes parallelus (Silvestri, 1923) & & $x$ & Colombia & {$[25,38,57,91,92]$} \\
\hline Syntermes spinosus (Latreille, 1804) & & $x$ & Brazil, Colombia, Venezuela & {$[4,25,38,54,57,91,92]$} \\
\hline Syntermes tanygnathus (Constantino, 1995) & & $x$ & Colombia & {$[25,53]$} \\
\hline Termes fatalis (Linnaeus, 1758) & & $x$ & Guyana, Indonesia & {$[25,38]$} \\
\hline
\end{tabular}

grasshoppers [106]. In a survey on the consumption of termites held in Côte d'Ivoire, from 500 people surveyed, 97\% consumed or had consumed termites, demonstrating that such use is part of the reality of rural and urban populations in that country, showing a consumption driven by the nutritional value, flavour and aroma of these insects, as well as by the curiosity of the people who consume them [22]. It is noticeable that some species are widely consumed in some countries, suggesting a preference for them, especially those belonging to the genus Macrotermes. This predilection, according to Mitsuhashi [107], may be related to differences in the nutritional composition of the genus Macrotermes, since they have high levels of proteins and lipids. This may explain why most of the compiled species (37\%) in our review belong to this genus. In Africa, this genus is abundant. They are known as "big termites", and are considered one of the favourite foods, not only of humans but also of gorillas and chimpanzees $[83,88,105]$, thus revealing a curious aspect of termite consumption by humans, since they are also consumed by animals phylogenetically close to humans.

Geographically, among the compiled studies, the highest number of termite species used for food compiled in

Table 2 Termite species used in traditional folk medicine

\begin{tabular}{|c|c|c|c|c|}
\hline \multirow[t]{2}{*}{ Termite species/family } & \multicolumn{2}{|l|}{ Use } & \multirow[t]{2}{*}{ Country(ies) } & \multirow[t]{2}{*}{ Reference(s) } \\
\hline & Treated diseases & Several & & \\
\hline \multicolumn{5}{|l|}{ Hodotermitidae } \\
\hline $\begin{array}{l}\text { Hodotermes mossambicus } \\
\text { (Hagen, 1853) }\end{array}$ & Child malnutrition & & Zambia & {$[62]$} \\
\hline \multicolumn{5}{|l|}{ Termitidae } \\
\hline $\begin{array}{l}\text { Macrotermes bellicosus } \\
\text { (Smeathman, 1781) }\end{array}$ & Suture wounds & & Somalia & {$[101]$} \\
\hline $\begin{array}{l}\text { Macrotermes nigeriensis } \\
\text { (Sjoestedt, 1911e) }\end{array}$ & $\begin{array}{l}\text { Sickness in pregmant women, } \\
\text { Wounds }\end{array}$ & $\begin{array}{l}\text { Spiritual protection against witches } \\
\text { and wizards, rituals protection and } \\
\text { promotion (in jobs, trade), appealing } \\
\text { to gods and witches, safe delivery of } \\
\text { baby, soothsaying (Afose) }\end{array}$ & Nigeria & {$[18,61]$} \\
\hline $\begin{array}{l}\text { Microcerotermes exiguus } \\
\text { (Hagen, 1858) }\end{array}$ & $\begin{array}{l}\text { Asthma, Bronchitis, Influenza, } \\
\text { Whooping Cough, Flu }\end{array}$ & & Brazil & {$[6,11,18,61,72,75,99]$} \\
\hline $\begin{array}{l}\text { Nasutitermes corniger } \\
\text { (Motschulsky, 1855) }\end{array}$ & $\begin{array}{l}\text { Asthma, Cough, Flu, and sore } \\
\text { throat, Antibiotic activity, } \\
\text { Antimicrobial }\end{array}$ & $\begin{array}{l}\text { Chickens' gogo (infectious coryza, a } \\
\text { type of cold)/ Honey }\end{array}$ & Brazil & {$[15,18,66,68-70,73]$} \\
\hline $\begin{array}{l}\text { Nasutitermes macrocephalus } \\
\text { (Silvestri, 1903) }\end{array}$ & $\begin{array}{l}\text { Asthma, Leakage, Bronchitis, 'catarrh } \\
\text { in the chest' coughs, influenza, sore } \\
\text { throat, sinusitis, tonsillitis and } \\
\text { hoarseness }\end{array}$ & & Brazil & {$[6,16,18,65,67,71,73-75,100]$} \\
\hline $\begin{array}{l}\text { Odontotermes feae } \\
\text { (Wasmann, 1896) }\end{array}$ & Asthma & & India & {$[20]$} \\
\hline $\begin{array}{l}\text { Odontotermes formosanus } \\
\text { (Shiraki, 1909) }\end{array}$ & $\begin{array}{l}\text { Ulcer, Better health, Body pain, } \\
\text { Rheumatics, Anemia, The } \\
\text { Enhacement of lactation }\end{array}$ & & India & {$[14,20,70,102]$} \\
\hline $\begin{array}{l}\text { Pseudacanthotermes spiniger } \\
\text { (Sjoestedt, 1900) }\end{array}$ & $\begin{array}{l}\text { Antifungal and antibacterial } \\
\text { properties }\end{array}$ & & Brazil & {$[15,20,63,64]$} \\
\hline
\end{tabular}


the present review was documented in Africa and South America, corroborating Ramos-Elorduy [108] who also identified the Americas and Africa as the areas with the highest number of insect species consumed as food. Complementing this information, in Asia, there is a large number of insects used as food by people [25]. One should also point out that most ethnobiological studies that reported the use of termites by humans were carried out in countries of Africa and the Americas, a fact that influenced the results in our review. Currently, more attention is given to alternative food resources traditionally used by humans, which, if used or exploited, are likely to be a more sustainable solution to nutrient deficiency among human populations [76]. In addition, as we can see in our review, termites can provide an important contribution in this regard.

The use of termites as a therapeutic resource also revealed an important mode of use of these animals. Evidence of antimicrobial activity of products isolated from these animals has been reported, such as peptides like espinigerine and termicine, isolated from Pseudocanthotermes spiniger, which showed antifungal and antibacterial activities [109]. In the compiled studies, a frequency of Nasutitermes macrocephalus (Silvestri, 1903) can be seen in the treatment of various diseases. Studies addressing the molecular biology of termites from the genus Nasutitermes demonstrated their potential as antimicrobial peptide producers $[110,111]$. Chaves et al. [112] suggest that Nasutitermes corniger and its nest are promising natural products for use in antimicrobial therapy. In a broader perspective, insects has significant potential as a source of medicinally relevant substances [5]. In this context, the use of termites, because of their wide use in traditional medical systems worldwide, indicates that these animals deserve to be further investigated from a pharmacological perspective. The pharmacological activity of termites could contribute to valorize these animals, whose negative aspects associated with the damage they cause to humans are often highlighted.

The compiled results revealed that several species of termites have historically been used by humans for food or medicinal use, showing a facet of human/termite interaction that, most of the time, is little known, and that, in a way, is masked by the negative perception that most people have of these insects. It has been ascertained that the value of termites as a source of food or popular remedies is widespread in many countries of the world, showing that these animals have been historically exploited by humans from a utilitarian perspective, an aspect that, combined with their ecological importance, may contribute to demystifying the negative view associated with these insects.

\section{Competing interests}

The authors declare that they have no competing interests.

\section{Authors' contributions}

RECRF and ISP worked in the bibliographical classification and the article final composition. AV and RRNA worked in conception and the article final composition. The authors read and approved the final manuscript.

\section{Acknowledgements}

We thank to CAPES (Coordenação de Aperfeiçoamento de Pessoal de Nível Superior) for providing a M.Sc. Scholarship to ISP and to CNPq (Conselho Nacional de Desenvolvimento Científico e Tecnológico) for providing a research fellowship to AV and RRNA.

\section{Author details}

${ }^{1}$ Departamento de Sistemática e Ecologia, CCEN, Universidade Federal da Paraíba, Laboratório de Termitologia, 58051-900 João Pessoa, PB, Brazil.

2Departamento de Biologia, Universidade Estadual da Paraíba, Laboratório de Termitologia, 58051-900 João Pessoa, PB, Brazil.

Received: 27 January 2015 Accepted: 14 March 2015

Published online: 30 April 2015

\section{References}

1. Alves RRN, Mendonça LET, Confessor MVA, Vieira WLS, Lopez LCS. Hunting strategies used in the semi-arid region of northeastern Brazil. J Ethnobiol Ethnomed. 2009:5:1-16.

2. Alves RRN. Relationships between fauna and people and the role of ethnozoology in animal conservation. Ethnobiology and Conservation. 2012;1:1-69.

3. Meyer-Rochow VB, Chakravorty J. Notes on entomophagy and entomotherapy generally and information on the situation in India in particular. Appl Entomol Zool. 2013;48:105-12.

4. Raubenheimer D, Rothman J. Nutritional Ecology of Entomophagy in Humans and Other Primates. Annu Rev Entomol. 2012;58:141-60.

5. Dossey AT. Insects and their chemical weaponry: New potential for drug discovery. Nat Prod Rep. 2010;27:1737-57.

6. Alves RRN, Alves HN. The faunal drugstore: Animal-based remedies used in traditional medicines in Latin America. J Ethnobiol Ethnomed. 2011;7:1-43.

7. Alves RRN, Albuquerque UP. Animals as a Source of Drugs: Bioprospecting and Biodiversity Conservation. In: Alves RRN, Rosa IL, editors. Animals in Traditional Folk Medicine: Implications for Conservation. Heidelberg: Springer; 2013. p. 67-89.

8. Costa-Neto EM. Entomotherapy, or the Medicinal Use of Insects. J Ethnobiol. 2005;25:93-114.

9. Meyer-Rochow VB. Entomophagy and its impact on world cultures: the need for a multidisciplinary approach. In: Durst PB, Johnson DV, Leslie RN, Shono K, editors. Forest insects as food: humans bite back. Thailand: Food and Agriculture Organization of the United Nations; 2010. p. 23-36.

10. Srivastava SK, Babu N, Pandey H. Traditional insect bioprospecting-As human food and medicine. Indian J Tradit Knowl. 2009:8:485-94.

11. Costa-Neto EM. The Use of Insects in Folk Medicine in the State of Bahia, Northeastern Brazil, With Notes on Insects Reported Elsewhere in Brazilian Folk Medicine. Hum Ecol. 2002;30:245-63.

12. Lee KE, Wood TG. Termites and Soils. New York: Academic Press; 1971.

13. Vasconcellos A, Moura FMS. Wood litter consumption by three species of Nasutitermes termites in an area of the Atlantic Coastal Forest in northeastern Brazil. J Insect Sci. 2010;10(72):1-9.

14. Solavan A, Paulmurugan R, Wilsanand V. Effect of the subterranean termite used in the South Indian folk medicine. Indian J Tradit Knowl. 2006:5:376-9.

15. Coutinho HDM, Vasconcellos A, Lima MA, Almeida-Filho GG, Alves RRN. Termite usage associated with antibiotic therapy: enhancement of aminoglycoside antibiotic activityby natural products of Nasutitermes corniger (Motschulsky 1855). BMC Complement Altern Med. 2009:9(35):1-4.

16. Lima JRB, Santos CAB. Recursos Animais Utilizados na medicina Tradicional dos Índios Pankararu no Nordeste do Estado de Pernambuco, Brasil. Etnobiologia. 2010:8:39-50.

17. Alves RRN. Fauna used in popular medicine in Northeast Brazil. J Ethnobiol Ethnomed. 2009:5:1-30.

18. Alves RRN, Dias TL. Usos de invertebrados na medicina popular no Brasil e suas implicações para conservação. Tropical Conservation Science. 2010;3:159-74.

19. Van-Huis H. Insects as food in Sub-Saharan Africa. Insect Science and its Application. 2003;23:163-85. 
20. Wilsanand V. Utilization of termite, Odontotermes formosanus by tribes of South India in medicine and food. Nat Prod Rad. 2005;4:121-5.

21. Johnson DV. The contribution of edible forest insects to human nutrition and to forest management: current status and future potential. In: Durst PB, Johnson DV, Leslie RN, Shono K, editors. Forest insects as food: humans bite back. Thailand: Food and Agriculture Organization of the United Nations; 2010. p. 5-22.

22. Niaba KV, Atchibri LO, Gbassi KG, Beugre AG, Adou M, Anon AB, et al. Consumption survey of edible winged termites in Cote d'Ivoire. Int J Agric Food Sci. 2012;2:149-52.

23. Van-Huis $\mathrm{H}$. Potential of insects as food and feed in assuring food security. Annu Rev Entomol. 2013:58:563-83.

24. Shockley M, Dossey AT. Insects for Human Consumption. In: Morales-Ramos J, Rojas G, Shapiro-llan DI, editors. Mass Production of Beneficial Organisms. London: Elsevier; 2014. p. 617-52.

25. Jongema, Y. List of edible insect species of the world. 2014 [cited 201405 november]; http://www.wageningenur.nl/en/Expertise-Services/Chairgroups/Plant-Sciences/Laboratory-of-Entomology/Edible-insects/Worldwidespecies-list.htm]

26. Moussa JB. Les chenilles comestibles du Congo: Intérêt alimentaire et circuits de commercialisation: Cas de Brazzaville. Rome: Rapport de Consultation. Food and Agriculture Organization of the United Nations; 2002.

27. Hoare AL. The use of non-timber forest products in the Congo Basin: Constraints and opportunities. The Rainforest Foundation. 2007;1:1-57.

28. Malaisse F. Se nourir en foret Claire africaine: approche ecologique et nutritionnelle. Gembloux: Les Presses Agronomiques de Gembloux; 1997.

29. Oliveira JFS, Carvalho RFXP, Sousa B, Simão MM. The nutritional value of four species of insects consumed in Angola. Ecol Food Nutr. 1976;5:91-7.

30. Silow CA. Notes on Ngangela and Nkoya Ethnozoology ants and termites. Goteborg: Goteborgs Etnografiska Museum; 1983.

31. Mbata KJ. Traditional use of arthropods in Zambia. Food Insects Newsletters. 1995;8:5-7.

32. Bahuchet. Les pygmées Aka et la forêt Centrafricaine. Paris: Selaf; 1985.

33. Ponzetta MT. Rôle alimentaire des insects dans L'évolution humain. In: Motte-Florac E, Thomas JMC, editors. In Les "insectes" dans la tradition orale. Peeters, Paris: SELAF; 2003. p. 633.

34. Boesch C, Boesch $\mathrm{H}$. Tool Use and Tool Making in Wild Chimpanzees. Folia Primatol. 1990;54:86-99.

35. McGrew WC, Collins DA. Tool use by wild chimpanzees (Pan troglodytes) to obtain termites (Macrotermes herus) in the Mahale Mountains, Tanzania. Am J Primatol. 1985;9:47-62.

36. McGrew WC, Roger E. Brief report: Chimpanzees, tools, and termites: New record from Gabon. Am J Primatol. 1983:5:171-4.

37. Sanz C, Morgan D, Gulick S. New Insights into Chimpanzees, Tools, and Termites from the Congo Basin. Am Nat. 2004;164:567-81.

38. DeFoliart GR. The human use of insects as food resource: a bibliographic account in progress. 2002; http://www.food-insects.com/book7_31/The\%20 Human\%20Use\%20of\%20Insects\%20as\%20a\%20Food\%20Resource.htm]

39. DeFoliart GR. Insects as food: Why the Western Attitude Important. Annu Rev Entomol. 1999:44:21-50.

40. Phelps RJ, Struthers JK, Moyo SJL. Investigations into the Nutritive Value of Macrotermes falciger (Isoptera: Termitidae). Zoologia africana. 1975;10:123-32.

41. Blum MS. The limits of entomophagy: a discretionary gourmand in a world of toxic Insects. The Food Insects Newsletter. 1994;7:6-11.

42. Fasoranti JO, Ajiboye DO. Some edible insects of Kwara State, Nigeria. Am Entomol. 1993;39:113-6.

43. Kinyuru JN, Konyole SO, Kenji GM, Onyango CA, Owino VO, Owor BO, et al. Identification of traditional foods with public health potential for complementary feeding in western Kenya. J Food Res. 2012;1:148-58.

44. Roulon-Doko P. Chasse, cueillette ET cultures chez lês Gbaya de Centrafrique. Paris: L'Harmattan; 1998.

45. Nkouka E. Les insectes comestibles dans lês societes d'Afrique Centrale. Muntu. 1987;6:171-8.

46. Bequaert J. Insects as food: How they have augmented the food supply of mankind in early and recent times. Nat Hist J. 1921;21:191-200.

47. Ayieko MA, Nyambuga IA. Termites and lake flies in the livelihood of households within the Lake Victoria region: Methods for harvesting and utilization. Technical report for the National Museums of Kenya, Research Program on Sustainable Use of Dryland Biodiversity, National Museums of Kenya, Nairobi, Kenya; 2009:1-11.

48. Chavanduka DM. Insects as a source of protein to the Africain. The Rhodesia Science News. 1976;9:217-20.
49. Banjo AD, Lawal OA, Songonuga EA. The nutritional value of fourteen species of edible insects in Southwestern Nigeria. Afr J Biotechnol. 2006;5:298-301.

50. Bodenheimer FS. Insects as human food: a chapter of the ecology of man. Dordrecht: The Hague; 1951.

51. Costa-Neto EM, Ramos-Elorduy J. Los insectos comestibles de Brasil: etnicidad, diversidad e importância em La alimentación. Bol Soc Entomol Aragon. 2006;38:423-42.

52. Paoletti $M G$, Buscardo $E$, Dufour DL. Edible invertebrates among Amazonian indians: a critical review of disappearing knowledge. Environ Dev Sustain. 2000;2:195-225.

53. Araujo Y, Beserra P. Diversidad de invertebrados consumidos por las etnias Yanomami y Yekuanadel Alto Orinoco, Venezuela. Interciencia. 2007;32:318-23.

54. Gahukar RT. Entomophagy and human food security. International Journal of Tropical Insect Science. 2001;31:129-44.

55. Hanboonsong Y. Edible insects and associated food habits in Thailand. In: Durst PB, Johnson DV, Leslie RN, Shono K, editors. In Forest insects as food: humans bite back. Thailand: Food and Agriculture Organization of the United Nations; 2010. p. 173-82.

56. Chung AYC, Chey VK, Unchi S, Binti M. Edible insects and entomophagy in Sabah, Malaysia. The Malayan Nature Journal. 2002;56:131-44.

57. Chen $X$, Feng $Y$, Chen $Z$. Common edible insects and their utilization in China. Entomological research. 2009;39:299-303.

58. Chen X, Feng Y. The edible insects of Chin. Beijing, China: Science and Technology Publishing House; 1999.

59. Nomura H. Entomologia pitoresca I - Os insetos nas crenças, superstições e medicina popular. Análise bibliográfica Sitientibus Série Ciências Biológicas. 2006:6:145-58.

60. Sousa RS. Etnobotânica e Etnozoologia de Comunidades Pesqueiras da Área de Proteção Ambiental (APA) do Delta do Parnaíba, Nordeste do Brasil. MSc. dissertation. Universidade Federal do Piauí, Teresina; 2010.

61. Costa-Neto EM, Ramos-Elorduy J, Manuel PJ. Los Insectos Medicinales De Brasil: Primeros Resultados. Bol Soc Entomol Aragon. 2006;38:395-414.

62. Costa-Neto EM, Universidade Federal de São Carlos. Etnoentomologia no Povoado de Pedra Branca, Município de Santa Terezinha, Bahia.Um Estudo de Caso das Interações Seres Humanos/Insetos. PhD. thesis. 2003.

63. Coutinho HDM, Lôbo KM, Bezerra DAC, Lôbo I. Peptides and Proteins with antimicrobial activity. Indian J Pharmacol. 2008;40:3-9.

64. Coutinho HDM, Vasconcellos A, Freire-Pessoa HL, Gadelha CA, Gadelha TS, Almeida-Filho GG. Natural products from the termite Nasutitermes corniger lowers aminoglycoside minimum inhibitory concentrations. Pharmacogn Mag. 2010;6:1-4

65. Alves RRN, Leo Neto NA, Brooks SE, Albuquerque UP. Commercialization of animal-derived remedies as complementary medicine in the semi-arid region of Northeastern Brazil. J Ethnopharmacol. 2009;124:600-8.

66. Souto WMS, Mourão JS, Barboza RRD, Alves RRN. Parallels between zootherapeutic practices in ethnoveterinary and human complementary medicine in northeastern Brazil. J Ethnopharmacol. 2011;134:753-67.

67. Alves RRN, Lima HN, Tavares MC, Souto WMS, Barboza RRD, Vasconcellos A. Animal-based remedies as complementary medicines in Santa Cruz do Capibaribe, Brazil. BMC Complement Altern Med. 2008;8:1-9.

68. Souto WMS, Mourão JS, Barboza RRD, Mendonça LET, Lucena RFP, Confessor MVA, et al. Medicinal animals used in ethno veterinary practices of the 'Cariri Paraibano', NE Brazil. J Ethnobiol Ethnomed. 2011;7:1-19.

69. Ferreira FS, Albuquerque UP, Coutinho HDM, Almeida WO, Alves RRN. The Trade in Medicinal Animals in Northeastern Brazil. Evidence-Based Complementary and Alternative Medicine. 2012;2012:1-20.

70. Albuquerque UP, Melo JG, Medeiros MF, Menezes IR, Moura GJ, El-Deir ACA, et al. Natural Products from Ethno directed Studies: Revisitingthe Ethnobiology of the Zombie Poison. Evidence-Based Complementary and Alternative Medicine. 2012;2012:1-19.

71. Alves RRN, Barbosa JAA, Santos SLDX, Souto WMS, Barboza RRD. Animal-Based Remedies as Complementary Medicines in the Semi-Arid Region of Northeastern Brazil. Evidence-Based Complementary and Alternative Medicine. 2011;2011:1-15.

72. Alves RRN, Silva CC, Barboza RRD, Souto WMS. Zootherapy as an alternative Therapeutic in South America. J Alt Med. 2009;1:21-47.

73. Alves RRN, Soares TCS, Mourão JS. Uso De Animais Medicinais Na Comunidade De Bom Sucesso, Soledade, Estado Da Paraíba, Brasil. Sitientibus Série Ciências Biológicas. 2008;8:142-7. 
74. Alves RRN, Oliveira MG, Barboza RRD, Singh R, Lopez LCS. Medicinal Animals as Therapeutic Alternative in a Semi-Arid Region of Northeastern Brazil. Forsch Komplementmed. 2009;16:305-12.

75. Ferreira FS, Fernandes-Ferreira H, Leo Neto N, Brito SV, Alves RRN. The trade of medicinal animals in Brazil: current status and perspectives. Biodivers Conserv. 2013;22:839-70.

76. Kinyuru JN, Konyole SO, Roos N, Onyango CA, Owino VO, Owiuor BB, et al. Nutrient composition of four species of winged termites consumed in western Kenya. J Food Compos Anal. 2013;30:1-19.

77. Riggi L, Veronesi M, Verspoor R, MacFarlane C, Tchibozo S. Exploring entomophagy in Northern Benin: Practices, perceptions and possibilities. Book of Abstracts of Conference on Insects to Feed the World, The Netherlands 14-17 May 2014

78. Collins DA, McGrew WC. Termite fauna related to differences in tool-use between groups of chimpanzees (Pan troglodytes). Primates. 1987:8:457-71.

79. MCBeath N, McGrew WC. Tools used by wild chimpanzees to obtain termites at Mt. Assirik, Senegal: the influence of habitat. J Hum Evol. 1982;11:65-72.

80. McGrew WC. Chimpanzee Material Culture: Implications for Human Evolution. Cambridge: Cambridge University Press; 1992.

81. Sugiyama Y, Koman J. A preliminary list of chimpanzees' alimentation at Bossou, Guinea. Primates. 1987;28:133-47.

82. Suszuki S, Kuroda S, Nishihara T. Tool-set for termite fishing by chimpanzees in the Ndoki Forest. Congo Behaviour. 1995;132:219-35.

83. Deblauwe I, Janssens G. New insights in insect prey choice by chimpanzees and gorillas in southeast Cameroon: The role of nutritional value. Am J Phys Anthropol. 2008;135:42-55.

84. McGrew WC, Tutin C, Baldwin P. Chimpanzees, tools, termites: crosscultural comparisons of Senegal, Tanzania, and Rio Muni. Man. 1979;14:185-214.

85. Nishida T, Uehara S. Chimpanzees, tools and termites: another example from Tanzania. Curr Anthropol. 1980;21:671-2.

86. Uehara S. Seasonal changes in the techniques employed by wild chimpanzees in the Mahale Mountains, Tanzania, to feed on termites (Pseudacanthotermes spiniger). Folia Primatol. 1982;37:44-76.

87. Goodall J. The behavior of free-living chimpanzees in the Gombe Stream Reserve. Animal Behaviour Monographs. 1968;1:161-311.

88. Lesnik JL. Termites in the hominin diet: A meta-analysis of termite genera, species and castes as a dietary supplement for South African robust australopithecines. J Hum Evol. 2014;71:1-11.

89. Dufour DL. Insects as food: a case study from the northwest Amazon. Am Anthropol. 1987:89:383-97.

90. DeFoliart GR. An Overview of the role of edible in preserving biodiversity. Ecol Food Nutr. 1996;36:109-32.

91. Marconi S, Manzi P, Pizzoferrato I, Buscardo E, Cerda H, Hernandez DL, et al. Nutritional evaluation of terrestrial invertebrates as tradicional food in Amazonia. Biotropica. 2002;34:273-80.

92. Hamad I, Delaporte E, Raoult D, Bittar F. Detection of termites and other insects consumed by African great apes using molecular fecal analysis. Sci Rep. 2014:4:1-9.

93. Kinyuru JN, Kenji GM, Njoroge SM, Ayieko MA. Effect of processing methods on the in vitro protein digestibility and vitamin content of edible winged termite (Macrotermes subhylanus) and grasshopper (Ruspolia differens). Food Bioprocess Technol. 2010;3:778-82.

94. O'Malley RC, Power ML. The energetic and nutritional yields from insectivory for Kasekela chimpanzees. J Hum Evol. 2014;71:46-58.

95. Agbdye FS, Ofuya TL, Akindele SO. Some edible insect species consumed by the people of Benue state. Nigeria Pak J Nutr. 2009;8:946-50.

96. Womeni HM, Linder M, Tiencheu B, Mbiapo FT, Villeneuve P, Fanni J, et al. Oils of insects and larvae consumed in Africa: potential sources of polyunsaturated fatty acids. Ocl. 2009;16:230-5.

97. Chuanhui Yl, Qiuju HE, Wang L, Kuang R. The utilization of insect-resources in Chinese Rural Area. J Agric Sci. 2010;2:146-54.

98. DeFoliart GR. Insect fatty acids: similar to those or poultry and fish in their degree of unsaturation but higher in the polyunsaturates. Food Insects Newsl. 1991;4:1-4.

99. Branch LC, Silva MF. Folk Medicine of Alter do Chão, Pará, Brazil. Acta Amazon. 1983;13:737-97.

100. Oliveira ES. Uso e conservação da fauna por populações humanas no Rio Grande do Norte, Nordeste do Brasil. MSc. dissertation. Universidade Federal do Rio Grande do Norte, Departamento de Botânica, Ecologia e Zoologia; 2011.
101. Marie R, Strasbourg University. Contribution a I'histoire des insects en thérapeutique. Phd. thesis. 1955.

102. Wilsanand V, Preema V, Rajitha P. Therapeutics of insects and insects products in South Indian traditional medicine. Indian J Pharm. 2007;6:563-8.

103. Sileshi GW, Nyeko P, Nkunika POY, Sekematte BM, Akinnifesi FK, Ajayi OC. Integrating Ethno-Ecological and Scientific Knowledge of Termites for Sustainable Termite Management and Human Welfare in Africa. Ecol Soc. 2009;14:1-21.

104. Krishna K, Grimaldi DA, Krishna V, Engel MS. Treatise on the Isoptera of the World. New York: Bulletin of the American Museum of Natural History; 2013.

105. Deblauwe I. Temporal Variation in Insect-eating by Chimpanzees and Gorillas in Southeast Cameroon: Extension of Niche Differentiation. Int J Primatol. 2009:30:229-52.

106. Anankware PJ, Fening KO, Osekre E, Obeng-Ofori D. Insects as food and feed: a review. Int J Agric Res Rev. 2015;3:143-51.

107. Chang AYC. Edible insects and entomophagy in Borneo. In: Durst PB, Johnson DV, Leslie RN, Shono K, editors. Forest insects as food: humans bite back. Thailand: Food and Agriculture Organization of the United Nations; 2010: 141:150.

108. Mitsuhashi J. The future use of insects as human food. In: Durst PB, Johnson DV, Leslie RN, Shono K, editors. Forest insects as food: humans bite back. Thailand: Food and Agriculture Organization of the United Nations; 2010. p. 115-22.

109. Ramos-Elorduy J. Insects: a hopeful food source. In: Paoletti MG, editor. Ecological implications of minilivestock. Enfield NH, USA: Science Pub; 2005. p. 263-91.

110. Lamberty M, Zachary D, Lanot R, Bordereau C, Robert A, Hoffmann JA, et al. Insect immunity constitutive expression of a cysteine-rich antifungal and a linear antibacterial peptide in a termite insect. J Biol Chem. 2001;276:4085-92.

111. Bulmer MS, Crozier RH. Duplication and diversifying selection among termite antifungal peptides. Mol Biol Evol. 2004;21:2256-64.

112. Bulmer MS, Crozier RH. Variation in positive selection in termite GNBPs and Relish. Mol Biol Evol. 2006;23:317-26.

113. Chaves TP, Clementino ELC, Felismino DC, Alves RRN, Vasconcellos A, Coutinho HDM, et al. Antibiotic resistance modulation by natural products obtained from Nasutitermes corniger (Motschulsky, 1855) and its nest. Saudi J Biol Sc. 2014. In press.

\section{Submit your next manuscript to BioMed Central and take full advantage of:}

- Convenient online submission

- Thorough peer review

- No space constraints or color figure charges

- Immediate publication on acceptance

- Inclusion in PubMed, CAS, Scopus and Google Scholar

- Research which is freely available for redistribution 